\title{
Eupatorium chinensis var. simplicifolium Root Extract Inhibits the Lipopolysaccharide- Induced Inflammatory Response in Raw 264.7 Macrophages by Inhibiting iNOS and cOX-2 Expression
}

\author{
Jin-Ho Lee ${ }^{1 \dagger}$, Dae-Hyun Kim ${ }^{1 \dagger}$, Ji-Won Shin', Sae-Jin Park', Yoon Suk Kim², Yusu Shin ${ }^{1}$, Ji-Yeon \\ $\mathrm{Yu}^{4}$ and Tack-Joong $\mathrm{Kim}^{1}$ * \\ ${ }^{1}$ Division of Biological Science and Technology, College of Science and Technology, Yonsei University, Wonju 220-710, Korea \\ ${ }^{2}$ Department of Biomedical Laboratory Science, College of Health Sciences, Yonsei University, Wonju 220-710, Korea \\ ${ }^{3}$ Department of Herbal Crop Research, National Institute of Horticultural and Herbal Science, RDA, Eumseong 369-873, Korea \\ ${ }^{4}$ Laboratory of Chemical Genomics, Korea Research Institute of Chemical Technology, Daejeon 305-600, Korea
}

Received July 8, 2012 /Revised August 1, 2012 /Accepted August 6, 2012

\begin{abstract}
Inflammation is a host defense mechanism that is activated in response to harmful substances or pathogens. However, an excessive inflammatory response is a problem in itself. Macrophages secrete inflammatory mediators such as nitric oxide (NO) or cytokines through various pathways such as the nuclear factor kappa B (NF- $\kappa \mathrm{B})$-activated pathway after recognizing pathogen-like lipopolysaccharides (LPSs). In this study, anti-inflammatory effects of Eupatorium chinensis var. simplicifolium (EUC) extracts were investigated using LPS-stimulated RAW 264.7 macrophages. The EUC root extract significantly reduced NO production, inducible nitric oxide synthase (iNOS) expression, and cyclooxygenase-2 expression in a concentration-dependent manner. In addition, the EUC root extract reduced phosphorylation of mitogen-activated protein kinases and protein kinase B, which is upstream of NF- $\kappa$ B. The EUC root extract also reduced the degradation of inhibitory kappa B. These results indicate that EUC root extract exerts anti-inflammatory effects, which are mediated by inhibition of iNOS expression and the NF- $\kappa$ B pathway.
\end{abstract}

Key words : Eupatorium chinensis var. simplicifolium, cyclooxygenase-2, inflammation, nitric oxide, NF- $\kappa$ B pathway

\section{Introduction}

Inflammation refers to the complex biological response caused by damaged cells and tissues, chemical irritants, or invading organisms such as bacteria $[8,17,31,34]$. Macrophages, a type of immune cell, are activated by bacterial lipopolysaccharide (LPS), interferon-gamma, and granulocyte-macrophage colony-stimulating factor [24]. Activated macrophages play an important role in inflammatory diseases by releasing various inflammatory cytokines such as IL-1 $\beta$, IL-6, TNF- $a$ as well as other inflammatory mediators such as nitric oxide (NO) and prostaglandins $[1,18,28]$. However, excessive production of inflammatory mediators can cause severe clinical symptoms, and is associated with various immune-mediated diseases such as rheumatoid arthritis [27].

Toll-like receptors (TLR) are a class of proteins that ini-

\footnotetext{
${ }^{\dagger}$ These authors contributed equally to this work.

*Corresponding author

Tel : +82-33-760-2242; Fax : +82-33-760-2183

E-mail: ktj@yonsei.ac.kr
}

tiate the innate immune response by recognizing the pathogen-associated molecular patterns of pathogens [1,23]. In mammals, 13 kinds of TLR have been identified. Among these, TLR4 forms a complex with CD14 and lymphocyte antigen 96 (MD2), and thus recognizes the complex of LPS, an endotoxin on the outer membrane of gram-negative bacteria, and LPS-binding protein $[7,14,20]$. Binding of LPS induces a conformational change in TLR4, which allows it to activate protein kinases, inducing an intracellular signaling cascade [24]. Two different types of pathways can be activated upon binding of LPS to the TLR4 receptor: myeloid differentiation primary response gene 88 (MyD88)-dependent pathways, and MyD88-independent pathways [8]. Some examples of these pathways are the mitogen activated protein kinase (MAPK) pathway, nuclear factor kappa B (NF-kB) pathway, and phosphatidylinositol 3-kinase/protein kinase B (PI3K/Akt) pathway [33,35].

MAPKs regulate inflammatory and immune responses by activating transcription factors such as activator protein-1, activating transcription factor-2, and NF- $\mathrm{kB}$ [20]. 
Extracellular signal-regulated kinases (ERKs), Jun N-terminal kinases/stress-activated protein kinases, and p38 kinases are all examples of MAPKs associated with LPS-induced expression of inducible nitric-oxide synthase (iNOS) and cyclooxygenase-2 (COX-2) in mouse macrophages [32].

$\mathrm{NF}-\mathrm{kB}$ is a transcription factor that induces expression of inflammatory genes [2]. It preexists in the cytoplasm bound by inhibitory kappa B (IKB), which maintains it in an inactive state [27]. When an appropriate signal is received, phosphorylation and degradation of IkB occur, which results in the activation of NF- $\mathrm{KB}$ and its translocation into the nucleus [25]. Akt is a component of several pathways in the cell. This protein phosphorylates Thr23 of IkB kinase, which is also associated with the activation of NF-kB $[11,12,30]$. Activated and translocated NF-kB subunits in the nucleus bind to NF- $\mathrm{kB}$ binding sites, and induce transcription of pro-inflammatory mediators such as iNOS, COX-2, TNF- $a$, IL-1 $\beta$, and IL-6 [21].

Nitric oxide is a free radical species produced by activated macrophage that has activity against pathogenic microbes and tumor cells [22,26]. iNOS, a type of NO synthase (NOS), produces high concentrations of $\mathrm{NO}$ compared to neuronal or endothelial NOS $[15,16]$. NO promotes inflammatory responses in several inflammatory diseases such as chronic inflammation, sepsis, and even death [6]. COX-2, an enzyme necessary for the synthesis of prostaglandins, is also associated with inflammatory responses [32].

Eupatorium chinensis var. simplicifolium (EUC) is a perennial plant in the family Asteraceae that has a wide distribution in Asia. This plant is used in Korean folklore medicine to treat various diseases such as influenza, acute bronchitis, rheumatoid disease, circulatory disease, skin disease, and constipation. However, the pharmacological mechanisms of this plant are unclear.

In this paper, it was proved that EUC root extract has anti-inflammatory effects and that it functions by inhibiting the production of iNOS and COX-2 in RAW 264.7 macrophages by inhibition of the NF-kB pathway.

\section{Materials and Methods}

\section{Extraction}

Eupatorium chinensis var. simplicifolium (EUC) cultivated according to the good agricultural practices method of the Korea Rural Development Administration was harvested in 2009 in Eumseong, Korea. For sample preparation, $200 \mathrm{~g}$ of dried roots, stems, or flowers of EUC plants were extracted three times with $2 \mathrm{~L}$ of $99 \%$ ethanol at $25^{\circ} \mathrm{C}$ for three days. The extracts were filtered through Whatman No. 1 paper and combined followed by concentration using a rotary evaporator (EYELA N-1000, Japan) at $40^{\circ} \mathrm{C}$. The extracts of $39 \mathrm{~g}, 4.53 \mathrm{~g}$, and $3.42 \mathrm{~g}$ from the roots, stems, and flowers were obtained, respectively. The extracts were dissolved in dimethylsulfoxide (DMSO) and Dulbecco's Modified Eagle's Medium (DMEM) was then added to achieve a final maximum DMSO concentration of $0.05 \%$.

\section{Cell culture}

Cells from the murine macrophage cell line RAW 264.7 were obtained from the American Type Culture Collection (ATCC, Rockville, MD, USA) and maintained in Dulbecco's modified Eagle's medium (DMEM, Sigma-Aldrich, St. Louis, MO, USA) supplemented with $10 \%$ heat-inactivated fetal bovine serum (FBS, Lonza, Walkersville, MD, USA), $100 \mathrm{U} / \mathrm{ml}$ of penicillin (Lonza, Walkersville, MD, USA), and $100 \mathrm{~g} / \mathrm{ml}$ of streptomycin (Lonza, Walkersville, MD, USA) in a humidified atmosphere of $5 \% \mathrm{CO}_{2}$ and $95 \%$ air at $37^{\circ} \mathrm{C}$.

\section{Nitrite assay}

RAW 264.7 macrophages at a concentration of $1 \times 10^{5}$ cells $/ \mathrm{ml}$ were seeded in 24-well plates and incubated with EUC extracts at various concentrations $(0,25,50$, and 100 $\mathrm{g} / \mathrm{ml}$ ) in the presence or absence of $100 \mathrm{ng} / \mathrm{ml}$ of LPS (Sigma-Aldrich, St. Louis, MO, USA) for $18 \mathrm{hr}$. The cell supernatant was mixed with an equal volume of Griess reagent ( $1 \%$ sulfanilamide, $0.1 \% \mathrm{~N}$-(1-naphthyl) ethylenediamine dihydrochloride, $2.5 \%$ phosphoric acid) for $10 \mathrm{~min}$ at room temperature. The absorbance was measured at $550 \mathrm{~nm}$ using a microplate reader, and sodium nitrite was used as a standard.

\section{Cytotoxicity assay}

RAW 264.7 macrophages $\left(2 \times 10^{4}\right.$ cells $\left./ \mathrm{ml}\right)$ were seeded in 96-well plates and incubated with EUC for $23 \mathrm{hr}$ at $37^{\circ} \mathrm{C}$. After incubation, cells were exposed to $10 \%$ of the volume of an EZ-Cytox kit (Daeil Lab Service Co., Ltd., Seoul, Korea) for $1 \mathrm{hr}$ at $37^{\circ} \mathrm{C}$. The absorbance at $450 \mathrm{~nm}$ was measured using a microplate reader to assess cytotoxicity.

\section{Western blot}

For western blot analyses, RAW 264.7 macrophages were pretreated with a range of concentrations of the EUC extracts 
in the presence or absence of LPS $(100 \mathrm{ng} / \mathrm{ml})$ for various times. Then, the cells were washed with $1 \mathrm{X}$ ice-cold phosphate buffered saline (PBS) and lysed in PRO-PREP lysis buffer (iNtRON Biotechnology, Seongnam, Korea). Protein concentrations were measured using the Bradford assay. Equal concentrations of cellular protein were separated by $10 \%$ SDS polyacrylamide gel electrophoresis and transferred to a polyvinylidene difluoride membrane. After blocking the membranes with $5 \%$ non-fat dry milk in TBS containing $0.05 \%$ Tween 20 (TBS-T) for $1 \mathrm{hr}$, each membrane was incubated overnight at $4^{\circ} \mathrm{C}$ in a 1:2,000 dilution of primary antibodies against iNOS, COX-2, phosphorylated forms of ERK1/2, Akt, or full-length IKBa. The membranes were washed three times with TBS-T, and then incubated in a 1:5,000 dilution of horseradish peroxidase-conjugated goat anti-rabbit IgG secondary antibody (Cell Signaling Technology) for $1 \mathrm{hr}$ at room temperature. Bands were detected using an enhanced chemiluminescence detection reagent (GE Healthcare, Buckinghamshire, UK).

\section{Results}

\section{Effect of EUC extracts on LPS-induced NO production in RAW 264.7 macrophages}

A nitric oxide assay was performed to investigate whether EUC extracts inhibited LPS-induced NO production. After stimulation of RAW 264.7 cells with LPS for $18 \mathrm{hr}$, NO production in the culture media increased markedly, to as high as $14.23 \pm 0.53 \mu \mathrm{M}$. The pretreatment of the cells with EUC root extract, stem extract, and flower extract, however, decreased the concentration of LPS-induced NO production to $0.81 \pm 0.16,1.86 \pm 0.14$, and $1.33 \pm 0.04 \mu \mathrm{M}$, respectively, compared to that produced in response to treatment with LPS alone (Fig. 1A). In addition, if the EUC extracts themselves have a toxic effect on cells, this effect must be distinguished from that caused by NO production, which also reduces the viability of LPS-treated cells. To confirm the cell cytotoxicity of EUC, it was investigated by incubating RAW 264.7 cells with the various EUC extracts for $24 \mathrm{hr}$ and then assessing cell death using the EZ-Cytox kit. The cell viability of cells pretreated with the root, stem, and flower extracts was $103.07 \pm 8.31,53.92 \pm 1.72$, and $53.92 \pm 0.97 \%$, respectively. Both EUC stem and flower extracts were cytotoxic, but not the EUC root extract (Fig. 1B).

In the LPS-induced RAW 264.7 cells pretreated with 25, 50, and $100 \mu \mathrm{g} / \mathrm{ml}$ of EUC root extract, the NO levels were
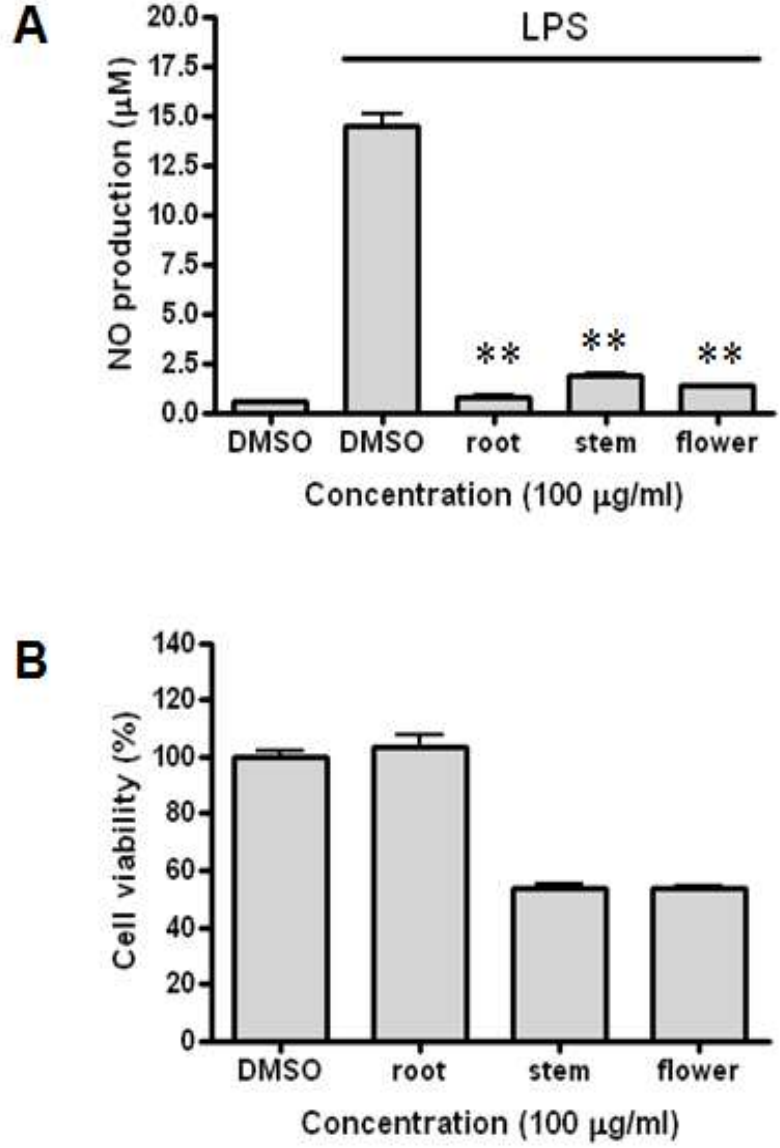

Fig. 1. Effects of EUC root, stem and flower extracts on nitric oxide production by RAW 264.7 macrophages and evaluation of the cytotoxicity of these extracts. (A) Effect of EUC root, stem and flower extracts on nitric oxide production in RAW 264.7 cells stimulated with LPS. Cells were pretreated with various concentrations of EUC or DMSO for $30 \mathrm{~min}$, followed by LPS (100 ng/ml) stimulation for $18 \mathrm{hr}$. The amount of nitrite in the culture supernatant was quantified using Griess reagent. (B) Cytotoxicity of EUC root, stem and flower extracts in RAW 264.7 cells. Cells were treated with $100 \mu \mathrm{g} / \mathrm{ml}$ of root, stem and flower extracts of EUC. After a 23-h incubation, cytotoxicity was evaluated using the EZ-Cytox kit. The results represent the averages of four similar experiments, and are expressed as means \pm SD. $\left({ }^{* *} p<0.01\right)$

$5.68 \pm 2.23,2.02 \pm 1.28$, and $1.06 \pm 0.04 \mu \mathrm{M}$, respectively (Fig. $2 \mathrm{~A}$ ). As shown in Fig. 2B, the cell viability of RAW 264.7 cells pretreated with 25,50 , and $100 \mu \mathrm{g} / \mathrm{ml}$ of EUC root extract was $94.71 \pm 16.72,94.03 \pm 11.75$, and $92.18 \pm 7.66 \%$, respectively, indicating that EUC root extract concentrations of 25 to 100 $\mu \mathrm{g} / \mathrm{ml}$ did not adversely affect the viability of RAW 264.7 cells. From these results, it was concluded that EUC root extract markedly inhibited the production of NO in LPS-induced RAW 264.7 cells in a concentration-dependent manner. 

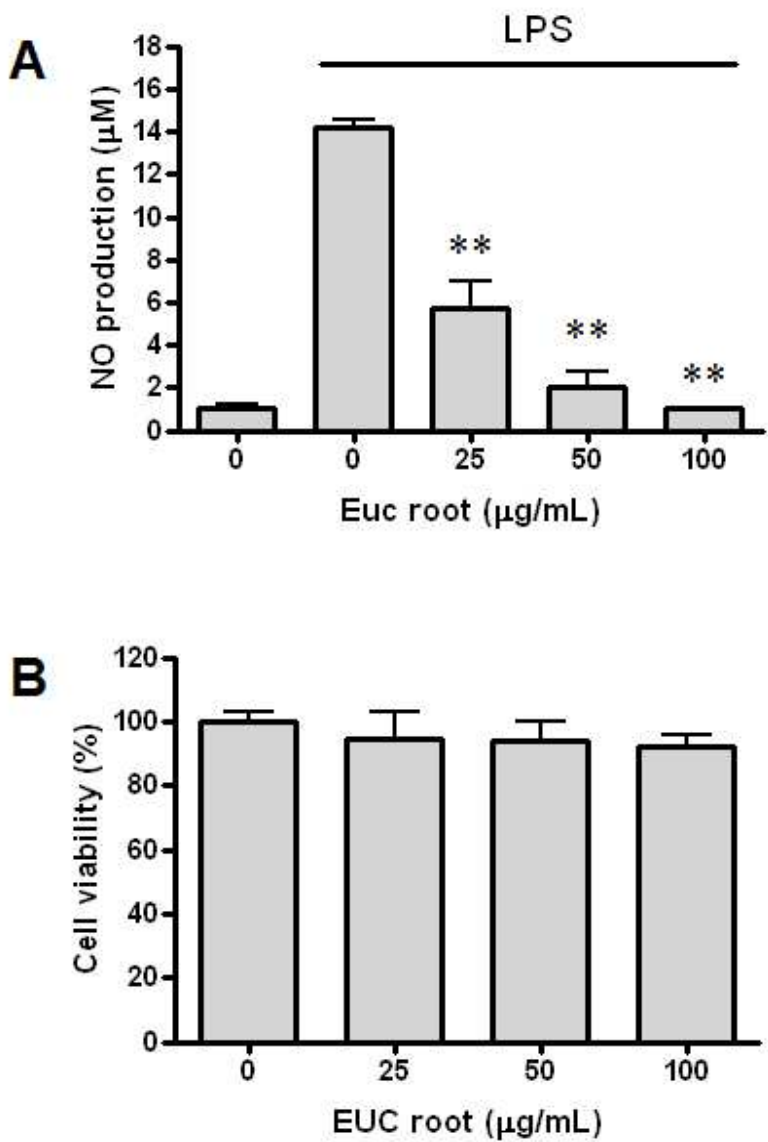

Fig. 2. Root extract of EUC dose-dependently decreases nitric oxide production in RAW 264.7 macrophages. (A) EUC root extract dose-dependently decreased nitric oxide production in RAW 264.7 cells stimulated with LPS. Cells were pretreated with various concentrations of EUC root extract or DMSO for $30 \mathrm{~min}$, and then stimulated with LPS $(100 \mathrm{ng} / \mathrm{ml})$ for $18 \mathrm{hr}$. The amount of nitrite in the culture supernatant was quantified using Griess reagent. (B) EUC root extract was not cytotoxic to RAW 264.7 cells. Cells were treated with various doses of EUC or DMSO. After a $23 \mathrm{hr}$ incubation, cytotoxicity was evaluated using the EZ-Cytox kit. The results represent the averages of four similar experiments, and are expressed as means \pm SD. $\left({ }^{* *} p<0.01\right)$

Effect of EUC root extract on the LPS-induced expression of iNOS and COX-2 in RAW 264.7 macrophages

To investigate whether the suppression of NO production was due to the down-regulation of iNOS expression, the expression of the iNOS protein was investigated. In addition, to determine the effect of the EUC root extract on COX-2 expression, the expression levels of COX-2 protein was analyzed. iNOS expression at EUC root extract concen-
A

\begin{tabular}{r|c|c|c|c|c|} 
LPS & - & + & + & + & + \\
\cline { 2 - 6 } EUC root $(\mu \mathrm{g} / \mathrm{mL})$ & $\mathbf{0}$ & $\mathbf{0}$ & $\mathbf{2 5}$ & $\mathbf{5 0}$ & 100 \\
\cline { 3 - 5 } & \\
iNOS & & & \\
\hline
\end{tabular}

B

\begin{tabular}{|c|c|c|c|c|c|}
\hline LPS & - & + & + & + & + \\
\hline EUC root $(\mu \mathrm{g} / \mathrm{mL})$ & 0 & 0 & 25 & 50 & 100 \\
\hline COX-2 & & & & & \\
\hline$\beta$-actin & & & & & \\
\hline
\end{tabular}

Fig. 3. EUC root extract decreases protein expression of iNOS and COX-2 in LPS-stimulated RAW 264.7 macrophages. Cells were pretreated with EUC root extract or DMSO for $30 \mathrm{~min}$, and then stimulated with LPS. After 6 or $12 \mathrm{hr}$ stimulation to measure iNOS (A) or COX-2 (B) expression, respectively, the cells were lysed and the lysates were examined by western blotting. Western blot bands were analyzed by densitometry and the values given are the percent of control. The results represent the average of four similar experiments, and are expressed as means \pm SD.

trations of 25 and $50 \mu \mathrm{g} / \mathrm{ml}$ was mildly reduced, but it was markedly suppressed by an EUC root extract concentration of $100 \mu \mathrm{g} / \mathrm{ml}$ (Fig. 3A). As a result, the EUC root extract inhibited iNOS protein expression in LPS-induced RAW 264.7 cells in a concentration-dependent manner. COX-2 expression, similar to iNOS expression, was also inhibited by EUC root extract in a concentration-dependent manner (Fig. 3B).

Effect of the EUC root extract on the LPS-induced phosphorylation of ERK1/2 and Akt in RAW 264.7 macrophages

Nextly, it was investigated the effect of the EUC root extract on the downstream signaling molecules ERK1/2 and Akt. The phosphorylation of ERK1/2 and Akt by western blot analysis was confirmed. As shown in Fig. 4, EUC root extract suppressed the LPS-induced phosphorylation of ERK1/2 and Akt in a concentration-dependent manner in LPS-treated RAW 264.7 macrophages. 
A

\begin{tabular}{|c|c|c|c|c|c|}
\hline LPS & - & + & + & + & + \\
\hline EUC root $(\mu \mathrm{g} / \mathrm{mL})$ & 0 & 0 & 25 & 50 & 100 \\
\hline P-ERK1/2 & & & $=$ & $=$ & - \\
\hline ERK1/2 & & & & & \\
\hline
\end{tabular}

B

\begin{tabular}{r|c|c|c|c|c|} 
LPS & - & + & + & + & + \\
\cline { 2 - 6 } EUC root $(\mu \mathrm{g} / \mathrm{mL})$ & 0 & 0 & 25 & 50 & 100 \\
\cline { 2 - 5 } P-Akt & & \\
\cline { 2 - 4 } & &
\end{tabular}

Fig. 4. EUC root extract inhibits the phosphorylation of ERK1/2 and Akt in LPS induced RAW 264.7 cells. Cells were pre-incubated with EUC root extract or DMSO for 30 min prior to stimulation with LPS for $30 \mathrm{~min}$ (for ERK1/2) or $45 \mathrm{~min}$ (for Akt). Total cell lysates were then obtained and examined by western blotting analysis using the antibodies indicated in the figure. Western blot bands were analyzed by densitometry and the values provided are percentages of the control. The results represent the average of four similar experiments, and are expressed as means $\pm \mathrm{SD}$.

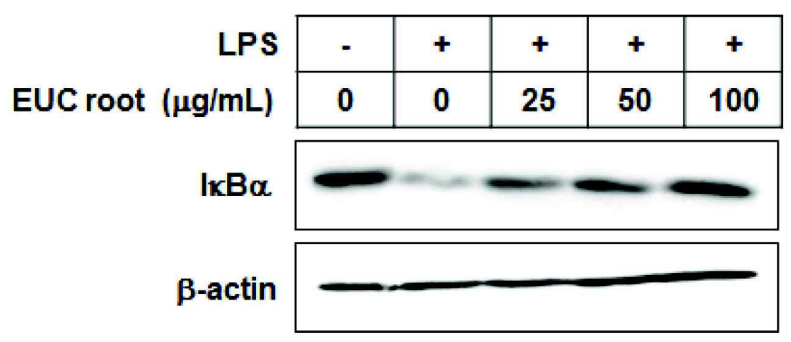

Fig. 5. EUC root extract prevents IkBa degradation in LPS-induced RAW 264.7 cells. Cells were treated with EUC root extract or DMSO for $30 \mathrm{~min}$ followed by stimulation with LPS for $30 \mathrm{~min}$. Total cell lysates were then obtained and IKBa levels were evaluated by western blotting analysis. Western blot bands were analyzed by densitometry and the values provided are percentages of the control. The results represent the average of four similar experiments.

Effect of EUC root extract on the LPS-induced degradation of $\mathrm{IkB}$ in RAW 264.7 macrophages

The IкB degradation was also investigated because this is a marker of activation of the NF-kB pathway. IkB protein levels were reduced by treatment with LPS alone. The EUC root extract restored IkB protein levels, however, in a concentration-dependent manner in LPS-induced RAW 264.7 macrophages (Fig. 5).

\section{Discussion}

The plant EUC belongs to the family Asteraceae. A number of plants of this family are traditionally used in folk medicines because of their pharmacologic effects $[4,13]$. However, few studies have investigated the underlying pharmacological mechanisms [13]. Chakaravarty et al. used ethanolic leaf extracts of Eupatorium adenophorum spreng (EA), family Asteracaeae, and reported that the extracts had anti-inflammatory potential [4]. This plant grows at an altitude of $800 \sim 2050 \mathrm{~m}$, and is used as an ingredient in folk remedies for treating oral and skin sores [4]. These authors showed that EA extracts increased the expression of TNF- $a$ and inhibited that of IL-13, COX-2, as well as decreased hydroxyl radical generation, thus the extracts had a general anti-inflammatory effect [4]. Eupatorium perfoliatum $L$, a North America native species widely used by native Indians, has also been shown to have anti-inflammatory effects [13]. Extracts of this plant inhibited NO release in LPS-induced RAW 264.7 cells and downregulated the expression of chemokines (CCL2, CCL22, CXCL10) and cytokines (IL-1a, IL-1 $\beta$, and CSF-3) [13].

$\mathrm{NO}$, a secretory product of mammalian cells, carries out important functions in homeostasis and host defense [26]. Excessive NO production, however, is associated with various diseases that involve inflammation, such as atherosclerosis, rheumatoid arthritis, and septic shock $[9,29]$. Thus, inhibition of NO production in inflammatory diseases is a potentially useful treatment strategy. In this study, EUC root extract was confirmed to significantly reduce LPS-induced NO production by RAW 264.7 macrophages. This suggests that EUC root extract could potentially be used to treat inflammation. In more detail, EUC root extract reduced iNOS protein levels in a concentration-dependent manner and concentration-dependently reduced COX-2 expression, which is associated with prostaglandin production that triggers pain or swelling when overproduced. Thus, the EUC root extract interfered directly with upstream mediators in the LPS-induced iNOS and COX-2 synthesis pathways.

MAPKs have been shown to be activated by LPS-induced up-regulation of iNOS expression [5,31]. In addition, the PI3K/Akt signal pathway is involved in NF-kB activation 
via I $\mathrm{kB}$ degradation, and LPS-activated NF- $\mathrm{BB}$ in macrophages induces transcript expression of iNOS and COX-2 $[12,19,21]$. NF-kB is a heterodimeric complex consisting of two subunits, p 65 and p50, and can bind to a specific cytokine promoter sequence $[3,10]$. NF- $k B$, which is usually inhibited by IkB, is activated by LPS-induced phosphorylation, and the $\mathrm{p} 65$ subunit then functions as a transcription factor and induces expression of specific genes such as that encoding iNOS [27]. In our study, EUC root extract concentration-dependently inhibited the phosphorylation of ERK1/2 and Akt and the degradation of IKB. EUC root extract therefore appears to reduce the expression of $\mathrm{iNOS}$ and COX-2 genes by inhibition of the MAPK pathway and NF- $k B$ activation.

Numerous studies have investigated the anti-inflammatory effects and underlying pharmacological mechanisms of various botanical extracts using LPS-induced macrophages $[4,6,35]$. Chao et al. reported ethyl acetate extracts of Angelica sinensis inhibited NF-kB luciferase activity in LPS-induced macrophages [6]. Moreover, extracts of the plant Sanguisorba officinalis were reported to exert anti-inflammatory effects by suppressing NF-kB [35]. Although extracts of plants in the genus Eupatorium show anti-inflammatory effects that appear to be mediated by inhibition of NO or pro-inflammatory cytokine production [13], the affected pathways and inflammatory mediators involved are not yet clear. In this study, it was proved that EUC root extract not only reduces NO production, but also directly affects the MAPK and NF-kB pathways. However, because multiple pathways controlling various cytokines and associated molecules may be involved, further extensive studies are required to investigate the anti-inflammatory mechanisms of EUC root extract in detail. In addition, because plants in the genus Eupatorium have also been reported to have anti-bacterial and oxidative effects, these should be explored in future studies.

In conclusion, EUC root extract inhibits the expression of COX-2 and iNOS and the production of NO by inhibiting the NF- $\mathrm{kB}$ pathway; specifically, the root extract inhibits ERK1/2 and Akt phosphorylation and IkB degradation. These findings suggest that EUC root extract has potential applications as an anti-inflammatory agent.

\section{Acknowledgements}

This research was supported by the Industrialization
Support Program for Agricultural and Forestry Biotechnology (810007-03-2-SB220), Ministry for Food, Agriculture, Forestry and Fisheries, Republic of Korea.

\section{References}

1. Akira, S., Uematsu, S. and Takeuchi, O. 2006. Pathogen recognition and innate immunity. Cell 124, 783-801.

2. Bonizzi, G. and Karin, M. 2004. The two NF-kappaB activation pathways and their role in innate and adaptive immunity. Trends Immunol. 25, 280-288.

3. Carter, A. B., Knudtson, K. L., Monick, M. M. and Hunninghake, G. W. 1999. The p38 mitogen-activated protein kinase is required for NF-kappaB-dependent gene expression. The role of TATA-binding protein (TBP). J. Biol. Chem 274, 30858-30863.

4. Chakravarty, A. K., Mazumder, T. and Chatterjee, S. N. 2011. Anti-inflammatory potential of ethanolic leaf extract of eupatorium adenophorum spreng. Through alteration in Production of TNF-a, ROS and expression of certain genes. Evid Based Complement Alternat. Med 471074, 1-10

5. Chan, E. D. and Riches, D. W. 2001. IFN-gamma + LPS induction of iNOS is modulated by ERK, JNK/SAPK, and p38(mapk) in a mouse macrophage cell line. Am J. Physiol. Cell Physiol. 280, C441-C450.

6. Chao, W. W., Hong, Y. H., Chen, M. L. and Lin, B. F. 2010. Inhibitory effects of Angelica sinensis ethyl acetate extract and major compounds on NF-kappaB trans-activation activity and LPS-induced inflammation. J. Ethnopharmacol. 129, 244-249.

7. Chen, T. L., Chang, C. C., Lin, Y. L., Ueng, Y. F. and Chen, R. M. 2009. Signal-transducing mechanisms of ketamine-caused inhibition of interleukin-1 beta gene expression in lipopolysaccharide-stimulated murine macrophage-like Raw 264.7 cells. Toxicol. Appl. Pharmacol. 240, 15-25.

8. Datla, P., Kalluri, M. D., Basha, K., Bellary, A., Kshirsagar, R., Kanekar, Y., Upadhyay, S., Singh, S. and Rajagopal, V. 2010. 9,10-dihydro-2,5-dimethoxyphenanthrene-1,7-diol, from Eulophia ochreata, inhibits inflammatory signalling mediated by Toll-like receptors. Br. J. Pharmacol. 160, 1158-1170.

9. Detmers, P. A., Hernandez, M., Mudgett, J., Hassing, H., Burton, C., Mundt S., Chun, S., Fletcher, D., Card, D. J., Lisnock, J., Weikel, R., Bergstrom, J. D., Shevell, D. E., Hermanowski-Vosatka, A., Sparrow, C. P., Chao, Y. S., Rader, D. J., Wright, S. D. and Puré, E. 2000. Deficiency in inducible nitric oxide synthase results in reduced atherosclerosis in apolipoprotein E-deficient mice. J. Immunol. 165, 3430-3435.

10. Ghosh, S., May, M. J. and Kopp, E. B. 1998. NF-kappa B and Rel proteins: evolutionarily conserved mediators of immune responses. Annu. Rev. Immunol. 16, 225-260.

11. Guha, M. and Mackman, N. 2002. The phosphatidylinositol 3-kinase-Akt pathway limits lipopolysaccharide activation of signaling pathways and expression of inflammatory me- 
diators in human monocytic cells. J. Biol. Chem 277, 32124-32132.

12. Hattori, Y., Hattori, S. and Kasai, K. 2003. Lipopolysaccharide activates Akt in vascular smooth muscle cells resulting in induction of inducible nitric oxide synthase through nuclear factor-kappa B activation. Eur. J. Pharmacol. 481, 153-158.

13. Hensel, A., Maas, M., Sendker, J., Lechtenberg, M., Petereit, F., Deters, A., Schmidt, T. and Stark, T. 2011. Eupatorium perfoliatum L.: phytochemistry, traditional use and current applications. J. Ethnopharmacol. 138, 641-651.

14. Hiransai, P., Ratanachaiyavong, S., Itharat, A., Graidist, P., Ruengrairatanaroj, P. and Purintrapiban, J. 2010. Dioscorealide B suppresses LPS-induced nitric oxide production and inflammatory cytokine expression in RAW 264.7 macrophages: The inhibition of NF-kappaB and ERK1/2 activation. J. Cell. Biochem 109, 1057-1063.

15. Hwang, Y. H., Kim, M. S., Song, I. B., Lim, J. H., Park, B. K. and Yun, H. I. 2009. Anti-inflammatory effects of talosin A via inhibition of NF-kappaB activation in lipopolysaccharide-stimulated RAW 264.7 cells. Biotechnol. Lett. 31, 789-795.

16. Jacobs, A. T. and Ignarro, L. J. 2001. Lipopolysaccharide-induced expression of interferon-beta mediates the timing of inducible nitric-oxide synthase induction in RAW 264.7 macrophages. J. Biol. Chem 276, 47950-47957.

17. Jung, H. W., Yoon, C. H., Park, K. M., Han, H. S. and Park, Y. K. 2009. Hexane fraction of Zingiberis Rhizoma Crudus extract inhibits the production of nitric oxide and proinflammatory cytokines in LPS-stimulated BV2 microglial cells via the NF-kappaB pathway. Food Chem Toxicol. 47, 1190-1197.

18. Kim, B. H., Lee, K. H., Chung, E. Y., Chang, Y. S., Lee, H., Lee, C. K., Min, K. R. and Kim, Y. 2006. Inhibitory effect of chroman carboxamide on interleukin- 6 expression in response to lipopolysaccharide by preventing nuclear factor-kappaB activation in macrophages. Eur. J. Pharmacol. 543, 158-165.

19. Lee, H. J., Joo, M., Abdolrasulnia, R., Young, D. G., Choi, I., Ware, L. B., Blackwell, T. S. and Christman, B. W. 2010. Peptidylarginine deiminase 2 suppresses inhibitory \{kappa\}B kinase activity in lipopolysaccharide-stimulated RAW 264.7 macrophages. J. Biol. Chem 285, 39655-39662.

20. Lee, S. J. and Lim, K. T. 2009. Inhibitory effect of ZPDC glycoprotein on the expression of inflammation-related cytokines through p38 MAP kinase and JNK in lipopolysaccharide-stimulated RAW 264.7 cells. Inflamm Res. 58, 184-191.

21. Lee, T. Y., Lee, K. C., Chen, S. Y. and Chang, H. H. 2009. 6-Gingerol inhibits ROS and iNOS through the suppression of PKC-alpha and NF-kappaB pathways in lipopolysaccharide-stimulated mouse macrophages. Biochem Biophys. Res. Commun. 382, 134-139.

22. Ma, J. S., Kim, W. J., Kim, J. J., Kim, T. J., Ye, S. K., Song, M. D., Kang, H., Kim, D. W., Moon, W. K. and Lee, K. H. 2010. Gold nanoparticles attenuate LPS-induced NO production through the inhibition of NF-kappaB and IFN-be-
ta/STAT1 pathways in RAW 264.7 cells. Nitric Oxide. 23, 214-219.

23. Martin, M., Rehani, K., Jope, R. S. and Michalek, S. M. 2005. Toll-like receptor-mediated cytokine production is differentially regulated by glycogen synthase kinase 3 . Nat. Immunol. 6, 777-784.

24. Martinez, F. O. 2011. Regulators of macrophage activation. Eur. J. Immunol. 41, 1531-1534.

25. Moon, E. Y. and Pyo, S. 2007. Lipopolysaccharide stimulates Epac1-mediated Rap1/NF-kappaB pathway in Raw 264.7 murine macrophages. Immunol. Lett. 110, 121-125.

26. Nathan, C. 1992. Nitric oxide as a secretory product of mammalian cells. FASEB J. 6, 3051-3064.

27. Oh, J. H., Kang, L. L., Ban, J. O., Kim, Y. H., Kim, K. H., Han, S. B. and Hong, J. T. 2009. Anti-inflammatory effect of 4-O-methylhonokiol, compound isolated from Magnolia officinalis through inhibition of NF-kappaB. Chem Biol. Interact. 180, 506-514.

28. Park, P. H., Kim, H. S., Jin, X. Y., Jin, F., Hur, J., Ko, G. and Sohn, D. H. 2009. KB-34, a newly synthesized chalcone derivative, inhibits lipopolysaccharide-stimulated nitric oxide production in RAW 264.7 macrophages via heme oxygenase-1 induction and blockade of activator protein-1. Eur. J. Pharmacol. 606, 215-224

29. Petros, A., Bennett, D. and Vallance, P. 1991. Effect of nitric oxide synthase inhibitors on hypotension in patients with septic shock. Lancet. 338, 1557-1558.

30. Rajaram, M. V., Ganesan, L. P., Parsa, K. V., Butchar, J. P., Gunn, J. S. and Tridandapani, S. 2006. Akt/Protein kinase $B$ modulates macrophage inflammatory response to Francisella infection and confers a survival advantage in mice. J. Immunol. 177, 6317-6324.

31. Reddy, D. B. and Reddanna, P. 2009. Chebulagic acid (CA) attenuates LPS-induced inflammation by suppressing NF-kappaB and MAPK activation in RAW 264.7 macrophages. Biochem Biophys. Res. Commun. 381, 112-117.

32. Sareila, O., Korhonen, R., Kärpänniemi, O., Nieminen, R., Kankaanranta, H. and Moilanen, E. 2008. Janus kinase 3 inhibitor WHI-P154 in macrophages activated by bacterial endotoxin: differential effects on the expression of iNOS, COX-2 and TNF-alpha. Int. Immunopharmacol. 8, 100-108.

33. Takeda, K. and Akira, S. 2004. TLR signaling pathways. Semin. Immund. 16, 3-9.

34. Wang, Y. H., Shen, Y. C., Liao, J. F., Lee, C. H., Chou, C. Y., Liou, K. T. and Chou, Y. C. 2008. Anti-inflammatory effects of dimemorfan on inflammatory cells and LPS-induced endotoxin shock in mice. Br. J. Pharmacol. 154, 1327-1338.

35. Yu, T., Lee, Y. J., Yang, H. M., Han, S., Kim, J. H., Lee, Y., Kim, C., Han, M. H., Kim, M. Y., Lee, J. and Cho, J. Y. 2011. Inhibitory effect of Sanguisorba officinalis ethanol extract on $\mathrm{NO}$ and $\mathrm{PGE}_{2}$ production is mediated by suppression of NF- $\kappa \mathrm{B}$ and AP-1 activation signaling cascade. J. Ethnopharmacol. 134, 11-17. 
초록 : Raw 264.7 대식세포에서 등골나물 뿌리 추출물의 염증반응 조절 분자 iNOS와 COX-2 발현 억제 효과

이진호 ${ }^{1} \cdot$ 김대현 ${ }^{1} \cdot$ 신지원 ${ }^{1} \cdot$ 박세진 $^{1} \cdot$ 김윤석 ${ }^{2} \cdot$ 신유수 ${ }^{3} \cdot$ 유지연 $^{4} \cdot$ 김택중 ${ }^{*}$

( ${ }^{1}$ 연세대학교 과학기술대학 생명과학기술학부, ${ }^{2}$ 연세대학교 보건과학대학 임상병리학과, ${ }^{3}$ 농촌진흥청 국립 원예특작과학원, ${ }^{4}$ 한국화학연구원)

염증반응은 유해한 물질이나 병원체에 대항하여 활성화되는 생체 방어 기전이다. 그러나 과도한 염증반응은 그 자체가 생체에 좋지 않은 영향을 미칠 수 있다. 대식세포는 지질다당류와 같은 병원체를 인식한 후, NF-kB 경로의 활성화를 포함한 다양한 경로를 통하여 산화질소와 같은 염증매개인자들을 분비하는 면역세포이다. 본 연구에서는 지질다당류로 활성화시킨 RAW 264.7 대식세포를 이용하여 등골나물(Eupatorium chinensis var. simplicifolium) 뿌리, 줄기 그리고 꽃 추출물들의 항염증 효과를 알아보았다. 그 중 등골나물 뿌리의 추출물은 농도 의존적으로 산화질소의 생성을 감소시켰으며, 산화질소 합성유도효소(inducible nitric oxide synthase)와 고리형 산소화효소-2(cyclooxygenase-2)의 발현을 통계적으로 유의하게 감소시켰다. 또한 등골나물 뿌리의 추출물은 NF$\kappa \mathrm{B}$ 경로에 있는 MAP (mitogen activated protein) 인산화효소와 단백질 인산화효소 B (protein kinase B)의 활성 화를 감소시켰으며, 억제적 kappa B (inhibitory kappa B)의 분해 또한 감소시키는 것을 관찰하였다. 이러한 결과 는 등골나물 뿌리의 추출물이 NF-kB 경로와 산화질소 합성유도효소 발현의 억제를 통하여 항염증작용을 나타낼 수 있음을 제시한다. 